\title{
Correlation of Electromyography and Magnetic Resonance Imaging Findings in the Diagnosis of Suspected Radiculopathy
} Şüpheli Radikülopati Tanısında Elektromiyografi ve Manyetik Rezonans Görüntüleme Bulgularinın Korelasyonu

\author{
Yıldız Arslan ${ }^{1}$, Ebru Yaşar ${ }^{2}$, Yaşar Zorlu1 \\ ${ }^{1}$ Tepecik Training and Research Hospital, Clinic of Neurology, İzmir, Turkey \\ 2Şevket Yılmaz Training and Research Hospital, Clinic of Neurology, Bursa, Turkey
}

\section{Summary}

Objective: Patients with pain or numbness without motor deficits are the most common group referred to electrophysiology laboratories as suspected radiculopathy. We wanted to investigate whether electromyography (EMG) was useful for this group in the diagnosis or therapy of radiculopathy. Our aim was to investigate the correlation and classification of EMG and magnetic resonance imaging (MRI) findings in the diagnosis of suspected radiculopathy.

Materials and Methods: We included 74 patients with a $\geq 2$-month history of numbness and pain in the neck and back that radiated into the arm or leg. Patients with diabetes mellitus, previous disc or spine operation, polyneuropathy, spinal cord diseases (tumor, infection or syrinxs), motor deficits, and abnormal nerve conduction studies were excluded.

Results: The mean age of the patients was $51.58 \pm 11.53$ years. In total, $41(55.4 \%)$ patients were women and $33(44.6 \%)$ were men; 48.8\% ( $\mathrm{n}=36)$ showed cervical radiculopathy and $51.2 \%(\mathrm{n}=38)$ exhibited lumbosacral radiculopathy. The most common MRI finding was protrusion (37.8\%), and the most common EMG finding was re-innervation (59.5\%). The correlation of MRI and EMG findings was significant in lumbar radiculopathy ( $\mathrm{p}=0.007)$, but not in the cervical radiculopathy results $(\mathrm{p}=0.976)$.

Conclusion: EMG and MRI findings were compatible for lumbar radiculopathy, but not for cervical radiculopathy in mild to moderate grades.

Keywords: Suspected radiculopathy, electromyography, magnetic resonance imaging

Öz

Amaç: Elektrofizyoloji laboratuvarına şüpheli radikülopati tanısıyla gönderilen hastaların çoğu motor defisit olmadan ağrı ve uyuşukluk şikayetiyle başvuran gruptur. Biz elektromiyografinin (EMG) bu grup hastalarda radikülopatinin tanı ve tedavisinde faydalı olup olmadığını araştırmak istedik. Amacımız şüpheli radikülopati tanısında EMG ve manyetik rezonans görüntüleme (MRG) bulgularının sınıflandırılması ve korelasyonunun araştırılmasıdır.

Gereç ve Yöntem: Çalışmaya en az 2 aydır boyunda ve belde başlayıp kola veya bacağa yayılan ağrı ve uyuşması olan 74 hasta dahil edildi. Diabetes mellitus, geçirilmiş disk veya omurga operasyonu, polinöropati, spinal kord hastalı̆̆ı olanlar (tümör, enfeksiyon veya sirinks gibi) ile motor defisit ve anormal sinir iletim çalışmaları olan hastalar dışlandı.

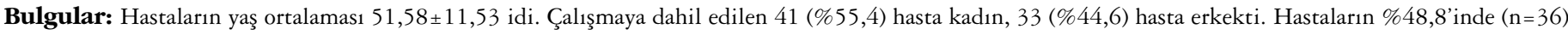
servikal radikülopati \%51,2'sinde $(\mathrm{n}=38)$ lumbosakral radikülopati saptandı. En sık görülen MRG bulgusu protrüzyon (\%37,8), en s1k görülen EMG bulgusu re-innervasyondu (\%59,5). EMG ve MRG bulgularının korelasyonu lomber radikülopatide istatistiksel olarak anlamlıydı ( $\mathrm{p}=0,007)$, ancak servikal radikülopati olanlarda anlamlı değildi ( $\mathrm{p}=0,976)$.

Sonuç: Hafif ve orta evre radikülopatide MRG ve EMG sonuçları lomber radikülopati de uyumlu saptandı, ancak servikal radikülopatide uyumlu değildi. Anahtar Kelimeler: Şüpheli radikülopati, elektromiyografi, manyetik rezonans görüntüleme 


\section{Introduction}

Cervical and lumbosacral radiculopathy is a common disorder that typically affects people in the fourth and fifth decades of life (1). Radiculopathy is characterized by inflammation or compression of nerve roots, producing pain and tingling, numbness, or even motor deficit along the distribution of the effected nerve root $(2,3)$. This process typically involves a herniated nucleus pulposis that compresses the nerve root within the spinal canal; alternatively, there may be an intrinsic lesion within the structure of the nerve root, such as a tumor, or demyelinating disease might underlie. If the root is only irritated, and not compressed, radiculitis results $(2,4)$. The other common cause of radiculopathy is spinal stenosis, which results from a combination of degenerative spondylosis, ligament hypertrophy, and spondylolisthesis (4). Symptoms of pain, numbness, and/or tingling may be mild or moderate, but radiculopathy is associated with motor weakness in severe cases. Efficient diagnosis and treatment can minimize pain, disability, and the direct and indirect costs of care (1). In most patients, symptoms are of short duration and resolve without treatment. Neurophysiologic tests in combination with neuroimaging, especially magnetic resonance imaging (MRI) because of its highresolution, have traditionally been used to assess patients with radiculopathy $(5,6,7)$. Electromyography (EMG) demonstrates a measure of the physiologic integrity of nerve roots, while MRI shows structural details of the roots and their surrounding tissues. Studies that examined the specific utility of EMG and MRI in the evaluation of clinical radiculopathy showed that although both are useful diagnostic tools, they have some limitations. EMG is likely to be negative if performed too early and may remain negative in radiculopathies that are mild or predominantly sensory, whereas MRI may reveal structural spinal abnormalities that are not clinically relevant, such as herniated intervertebral discs and spinal stenosis, which are frequently found in asymptomatic individuals or are irrelevant to the patients' symptoms $(7,8)$.

In the present study, we investigated the correlation between EMG and MRI findings in patients with suspected radiculopathy.

\section{Materials and Methods}

\section{Patients}

The medical records of 360 patients who were referred to our neurophysiology laboratory from neurology and neurosurgery outpatient clinics with a clinical pre-diagnosis of radiculopathy without motor deficit, between the dates June 2011 and May 2013 , were retrospectively reviewed. A total of 74 patients $(55.4 \%$ women) were included with a mean age of $51.58 \pm 11.53$ years. The inclusion criteria were presence of $\geq 2$-month history of numbness and pain in the neck and back that radiated to the arm or leg; being assessed with both neuroimaging and neurophysiologic studies; and having normal nerve conduction results and no motor deficits. A minimum of 8-week duration of symptoms was identified among the inclusion criteria to be able to observe denervation potentials and re-innervation. Patients with diabetes mellitus; history of intervertebral disk or spinal operations; polyneuropathy; spinal cord diseases such as tumors, infection or syrinx; abnormal nerve conduction; and motor deficit were excluded from study such that only mild and moderate radiculopathies were investigated.
In this retrospective study the data of subjects were collected with the permission of each subject and the study was performed in conformity with the Code of Etbics of the World Medical Association (Declaration of Helsinki), printed in the British Medical Journal (18 July 1964).

MRI findings were classified into four categories: degenerative abnormalities, bulging disc, protrusion, and nerve root compression. Similarly, EMG findings were divided into four groups: denervation, re-innervation, chronic neurogenic changes, and normal. Radiculopathy was graded as mild, moderate or severe. MRI and EMG findings and their correlation were classified and analyzed according to the following classification:

Mild: No motor or sensorial deficits, normal or re-innervation findings in EMG and normal nerve conduction study (NCS) findings. Degenerative abnormalities and/or bulging disc in MRI.

Moderate: No motor deficit, the presence of dermatomal hypoesthesia or hyperalgesia, normal NCS findings. Reinnervation, chronic neurogenic changes and/or denervation findings in EMG. Protrusion and nerve root compression findings in MRI.

Severe: The presence of motor and sensorial deficits. Denervation and chronic neurogenic changes findings in EMG. Nerve root compression in MRI.

\section{Electromyography Data}

We performed routine nerve conduction studies in all patients suspected to have radiculopathy using the Medelec Synergy EMG/ EP system (Oxford Instruments Medical, Inc., Oxford, UK). Nerve conduction studies and EMG were performed according to the 1999 guidelines of the American Association of Electrodiagnostic Medicine (AANEM). Ulnar, median motor and sensory nerves and sural, posterior tibial, and peroneal nerves were studied; median and tibial F-responses were also recorded. Concomitant polyneuropathy and nerve entrapment were investigated and excluded. A standard EMG examination using concentric needles was performed on each patient to assess for cervical and lumbosacral radiculopathy. The following muscles were examined for cervical radiculopathy: deltoid (C5/C6), biceps brachii (C5/C6), triceps brachii $(\mathrm{C} 6 / \mathrm{C} 7 / \mathrm{C} 8)$, brachioradialis $(\mathrm{C} 5 / \mathrm{C} 6)$, extensor digitorum communis $(\mathrm{C} 6 / \mathrm{C} 7)$, and abductor pollicis brevis $(\mathrm{C} 8 / \mathrm{Th} 1)$. The following muscles were examined for lumbosacral radiculopathy: tibialis anterior (L4/L5), peroneus longus (L5/S1), gastrocnemius medialis (S1/S2), and rectus femoris (L2/L3/L4). The presence of abnormal spontaneous fibrillation and/or positive sharp waves were interpreted as indicative of denervation, and a reduced number of motor unit action potentials (MUAPs) of increased duration was taken as a sign of chronic neurogenic change. Polyphasic and/or neurogenic (increased amplitude and duration) MUAPs were taken to indicate re-innervation. At least two muscles innervated by the same root were studied and interpreted. EMG findings of these muscles were recorded according to the pathologic root level as demonstrated using MRI.

\section{Magnetic Resonance Imaging Data}

MRI was performed using a standardized cervical and lumbar spine protocol (sagittal and transverse T1- and T2weighted sequences with a $4-\mathrm{mm}$ slice thickness) with a Philips Ingenia 1.5-T unit (Philips, Amsterdam, The Netherlands). Two experienced radiologists who were blinded to the patients' characteristics interpreted all MRI scans independently. The 
presence of degenerative abnormalities, bulging discs, protrusion, and nerve root compression were identified using the definitions of the American Society of Neuroradiology. Radiologic nerve root compression was the main outcome measure. Bulging disc was defined as the containment of the nucleus pulposus remains within the annulus fibrosus whereby the spinal canal was not narrowed, whereas protrusions occupied a wider space and narrowed the canal.

\section{Statistical Analyses}

Statistical analysis of the study data was performed using the Statistical Package for Social Sciences (SPSS) software for Windows (version 20.0; IBM Corp., Armonk, NY, USA). Descriptive statistics were performed to compare MRI and EMG findings and cervical and lumbar radiculopathy separately. Pearson's $\chi^{2}$ $(4 \mathrm{x} 4)$ test was used to assess the statistical significance of these associations; $\mathrm{p}<0.05$ was taken to indicate statistical significance.

\section{Results}

The patients' mean age was $51.58 \pm 11.53$ years. In total, $41(55.4 \%)$ patients were women and 33 (44.6\%) were men; $48.8 \%(n=36)$ had cervical radiculopathy and $51.2 \%(n=38)$ had lumbosacral radiculopathy. The most common MRI finding was protrusion $(37.8 \%)$, and the most common EMG finding was reinnervation (59.5\%). Four patients had normal MRI findings; of these, two exhibited reinnervation on EMG, and the other two showed chronic neurogenic changes on EMG. EMG findings were normal in 12 patients; 6 of which revealed protrusion on MRI, and 6 had bulging on MRI. Statistical analyses were performed in all patients for the comparison of EMG and MRI findings, and also for the comparison of cervical and lumbar radiculopathies. The two groups showed significant differences with regard to the MRI and EMG findings $(\mathrm{p}=0.037)$. Lumbar radiculopathy findings were also significantly different between the two groups ( $\mathrm{p}=0.007)$; but there was no significant difference in cervical radiculopathy findings $(\mathrm{p}=0.976)$. The overall MRI and EMG findings are described in Table 1. The cervical and lumbar findings are provided separately in Tables 2 and 3, respectively. MRI findings (normal, bulging, protrusion, and root compression) and EMG findings (normal, reinnervation, chronic neurogenic changes, and denervation) are also shown in the tables. Twelve patients exhibited chronic neurogenic changes, the most common of which was bulging on MRI $(n=7)$. A total of 44 patients revealed re-innervation: 16 had protrusion, 15 had root compression, and 11 had bulging on MRI. Only six patients had denervation potentials: two had root compression, three had protrusion, and one had bulging.

The most commonly involved root levels were C6-7 $(n=18)$, L4-5 ( $\mathrm{n}=19)$, and L5-S1 $(\mathrm{n}=18)$ in MRI. The second most common level of involvement was C5-6 ( $\mathrm{n}=13)$; involvement at L3-4, C4-5, and $\mathrm{C} 7-8$ levels was seen each in one patient. The remaining three lesions were at C8-T1. MRI and EMG findings are presented in Table 4 by root levels.

\section{Discussion}

The literature on the relative efficacy of MRI and EMG in the evaluation of radiculopathy and degree of correlation between these diagnostic tests is limited. A major restriction of diagnostic

\begin{tabular}{|c|c|c|c|c|c|}
\hline \multirow{2}{*}{$\begin{array}{l}\text { Total } \\
\text { EMG findings }\end{array}$} & \multicolumn{5}{|c|}{ MRI findings } \\
\hline & $\begin{array}{l}\text { Degenerative } \\
\text { abnormalities }\end{array}$ & Bulging & Protrusion & $\begin{array}{l}\text { Root } \\
\text { compression }\end{array}$ & Total \\
\hline Normal & $0(0 \%)$ & $6(24 \%)$ & $6(21.4 \%)$ & $0(0 \%)$ & $12(16.21 \%)$ \\
\hline Chronic neurogenic changes & $2(50 \%)$ & $7(28 \%)$ & $3(10.7 \%)$ & $0(0 \%)$ & $12(16.21 \%)$ \\
\hline Reinnervation & $2(50 \%)$ & $11(44 \%)$ & $16(57.1 \%)$ & $15(88.2 \%)$ & $44(59.45 \%)$ \\
\hline Denervation & $0(0 \%)$ & $1(4 \%)$ & $3(10.7 \%)$ & $2(11.8 \%)$ & $6(8.10 \%)$ \\
\hline Total & $4(5.40 \%)$ & $25(33.78 \%)$ & $28(37.83 \%)$ & $17(22.97 \%)$ & $74(100 \%)$ \\
\hline
\end{tabular}

\begin{tabular}{|c|c|c|c|c|c|}
\hline \multirow{2}{*}{$\begin{array}{l}\text { Cervical } \\
\text { EMG findings }\end{array}$} & \multicolumn{5}{|c|}{ MRI findings } \\
\hline & $\begin{array}{l}\text { Degenerative } \\
\text { abnormalities }\end{array}$ & Bulging & Protrusion & $\begin{array}{l}\text { Root } \\
\text { compression }\end{array}$ & Total \\
\hline Normal & $0(0 \%)$ & $1(10 \%)$ & $4(17.4 \%)$ & $0(0 \%)$ & $5(13.88 \%)$ \\
\hline Chronic neurogenic changes & $0(0 \%)$ & $2(20 \%)$ & $3(13 \%)$ & $0(0 \%)$ & $5(13.88 \%)$ \\
\hline Reinnervation & $1(100 \%)$ & $6(60 \%)$ & $13(56.5 \%)$ & $2(100 \%)$ & $22(61.11 \%)$ \\
\hline Denervation & $0(0 \%)$ & $1(10 \%)$ & $3(13 \%)$ & $0(0 \%)$ & $4(11.11 \%)$ \\
\hline Total & $1(2.77 \%)$ & $10(27.77 \%)$ & $23(63.88 \%)$ & $2(5.55 \%)$ & $36(100 \%)$ \\
\hline
\end{tabular}


studies of nerve root involvement is the absence of a gold standard method, because of the inherent limitations of all diagnostic methods and operative findings, which renders comparison of their relative diagnostic sensitivity controversial (3). Radiologic studies using MRI techniques only reveal structural abnormalities, which may also be present in asymptomatic patients or may be unrelated to clinical findings (8). MRI does not demonstrate inflammation of disk bulging or protrusion, and thus may not be able to distinguish between symptomatic and asymptomatic discs $(9,10)$. However, symptom onset and root compression and/ or irritation may not begin simultaneously. It is difficult to be certain that current symptoms provide chronic EMG changes, even if the symptom duration is chronic or an MRI abnormality, which frequently cannot be dated, is related to current symptoms (11). Therefore, neither root compression as indicated by MRI, nor clinical symptoms can be considered gold standard findings of radiculopathy.

EMG results remain negative if EMG is performed before denervation or after the disappearance of denervation findings, or if reinnervation has not occurred $(12,13)$. Patients with $\geq 2$ months duration of symptoms were chosen in this study to observe denervation potentials and reinnervation. Despite this classic data, Dillingham et al. (14) suggested that cervical and lumbosacral radiculopathy showed no evidence of correlation between spontaneous activity in the paraspinal and in other major proximal, or distal muscles and symptom duration (15). However, we aimed to observe the denervation potentials and re-innervation findings in this study. Chronic neurogenic changes typically persist indefinitely after radiculopathy and it is common to find such abnormalities for years after patients first exhibit symptoms. In our study, reinnervation was seen in $59.5 \%$ of the patients. This relatively high rate may be due to normal polyphasic findings, which may occur in $10 \%$ to $20 \%$ of normal limb muscles (13). We also observed a good correlation between EMG and MRI findings in most (78.37\%) patients who exhibited clinical signs of cervical or lumbosacral radiculopathy. The studies included in the AANEM review used a combination of clinical and radiologic findings; the nine studies cited in the final review were characterized by an overall needle EMG sensitivity of $50 \%$ to $71 \%$ in the context of diagnosis of radiculopathy, which the review described as moderate diagnostic sensitivity. Studies with a greater number of clinical motor deficits also reported higher sensitivities. According to Nardin et al., (7) compatibility between EMG and MRI findings was highest in patients with

\begin{tabular}{|c|c|c|c|c|c|}
\hline Lumbar & & & MRI findings & & \\
\hline EMG findings & $\begin{array}{l}\text { Degenerative } \\
\text { abnormalities }\end{array}$ & Bulging & Protrusion & $\begin{array}{l}\text { Root } \\
\text { compression }\end{array}$ & Total \\
\hline Normal & $0(0 \%)$ & $5(33.3 \%)$ & $2(40 \%)$ & $0(0 \%)$ & $7(18.42 \%)$ \\
\hline Chronic neurogenic changes & $2(66.7 \%)$ & $5(33.3 \%)$ & $0(0 \%)$ & $0(0 \%)$ & $7(18.42 \%)$ \\
\hline Re-innervation & $1(33.3 \%)$ & $5(33.3 \%)$ & $3(60 \%)$ & $13(86.7 \%)$ & $22(57.89 \%)$ \\
\hline Denervation & $0(0 \%)$ & $0(0 \%)$ & $0(0 \%)$ & $2(13.3 \%)$ & $2(5.26 \%)$ \\
\hline Total & $3(7.89 \%)$ & $15(39.47 \%)$ & $5(13.15 \%)$ & $15(39.47 \%)$ & $38(100 \%)$ \\
\hline
\end{tabular}

Table 4. Electromyography and magnetic resonance imaging findings according to root levels

\section{MRI findings}

Root Degenerative

level abnormalities

\section{Bulging Protrusion}

\section{EMG findings}

\begin{tabular}{|c|c|c|c|}
\hline $\begin{array}{l}\text { Root } \\
\text { compression }\end{array}$ & Normal & $\begin{array}{l}\text { Chronic } \\
\text { neurogenic }\end{array}$ & Denervation \\
\hline
\end{tabular}
innervation

Total changes

\begin{tabular}{llllllllll} 
C4-5 & 0 & 0 & 1 & 0 & 0 & 0 & 0 & 1 \\
C5-6 & 0 & 2 & 9 & 2 & 2 & 4 & 0 & 7 & 13 \\
C6-7 & 1 & 7 & 10 & 0 & 3 & 2 & 2 & 11 \\
C7-8 & 0 & 0 & 1 & 0 & 0 & 0 & 1 & 0 \\
C8-T1 & 0 & 1 & 2 & 0 & 0 & 0 & 1 & 2 \\
L3-4 & 0 & 1 & 0 & 0 & 0 & 1 & 0 & 1 \\
L4-5 & 0 & 6 & 3 & 10 & 4 & 1 & 1 & 13 \\
L5-S1 & 3 & 8 & 2 & 5 & 3 & 5 & 1 & 9 \\
Total & 4 & 25 & 28 & 17 & 12 & 13 & 6 & 43 \\
EMG: Electromyography, MRI: Magnetic resonance imaging & & & & 74 \\
\hline
\end{tabular}


a clear radicular syndrome accompanied by abnormal clinical findings (motor, sensory, or reflexes) consistent with radiculopathy (12). We also observed good agreement between diagnostic test results in patients without motor deficits and $\mathrm{F}$-waves in normal ranges. Based on these data, it is important to understand that a negative EMG or MRI study for radiculopathy does not rule out the presence of disease, and that clinical findings, particularly in motor deficits. In our study, a significant difference was found between cervical and lumbar radiculopathy. Additionally, EMG and MRI were compatible for lumbar radiculopathy $(\mathrm{p}<0.05)$, but not for cervical radiculopathy $(\mathrm{p}>0.05)$. This may have been due to differences in anatomy, myotomal innervation, spinal canal narrowness, or spinal nerve variance between the lumbar and cervical spines. Studies in the literature have reported that needle EMG was particularly helpful in determining false-positivity rates of lumbar spinal MRI, which are quite high, with $27 \%$ of normal subjects with disc protrusion in lumbar MRI; false-positivity rates for cervical MRI are much lower. However, we found much greater diagnostic discrepancy between MRI and EMG findings in cervical radiculopathy. Radiculopathies may also occur without any structural findings on MRI or without any EMG findings (4). An alternative possible explanation for this discrepancy might relate to an etiologic association between radiculopathy and inflammation, or permanent denervation activity with a resolved herniated disc (10).

This study had several limitations. First, we did not examine the paraspinal muscles. We attempted to reduce the effect of this shortcoming by including patients with $\geq 2$-month symptom duration referable to the disappearance of fibrillation potentials. However, denervation potentials might persist for years, even in paraspinal muscles. A second limitation concerned the clinical examination findings used to categorize patients. We only reviewed the muscle strength before the EMG study because of the retrospective design of our study; however, it would have been worthwhile if we had also been able to look for dermatomal hypoesthesia to grade radiculopathy and distinguish between mild and moderate cases. Finally, we had very few cases of cervical root compression $(n=2)$ compared with lumbar root compression $(n=15)$, which might account for the reported statistical difference.

\section{Conclusion}

In conclusion, we would like to emphasize the discrepancy between cervical and lumbar radiculopathy findings and the importance of obtaining reliable data before treatment or surgery for patients with radiculopathy with typical clinical signs and no motor deficits. EMG and MRI evidently represent complementary diagnostic tools for lumbosacral radiculopathy; however, reliable data are lacking for cervical radiculopathy. In our opinion, with the exception of those with severe radiculopathy, all patients should be managed conservatively. If root compression is present on MRI, EMG might help to discern the need for surgery. The question as to whether patients without motor deficits (i.e., those with only pain and numbness) should undergo surgery if EMG shows positive results (denervation or re-innervation) requires further prospective randomized studies with larger samples remains to be answered.

\section{Etbics}

Ethics Committee Approval: This retrospective study was approved by the Kocaeli Education and Research Hospital Local Ethics Committee. Informed Consent: A consent form was completed by all participants. Peer-review: Internal peer-reviewed.

\section{Authorship Contributions}

Concept and Design: Yildiz Arslan, Data Collection or Processing: Yıldız Arslan, Ebru Yaşar, Analysis or Interpretation: Yıldız Arslan, Ebru Yaşar, Literature Search: Yildiz Arslan, Writing: Yıldiz Arslan, Editing: Yaşar Zorlu, Medical Practices: Yıldiz Arslan, Ebru Yaşar. Conflict of Interest: No conflict of interest was declared by the authors. Financial Disclosure: The authors declared that this study has received no financial support.

\section{References}

1. Hakimi K, Spanier D. Electrodiagnosis of cervical radiculopathy. Physical Medicine and Rehabilitation Clinics of North America 2013;24:1-12.

2. Nasca RJ. Cervical radiculopathy: Current diagnostic and treatment options. J Surg Orthop Adv 2009;18:13-18.

3. Soltani ZR, Sajadi S, Tavana B. A comparison of magnetic resonance imaging with electrodiagnostic findings in the evaluation of clinical radiculopathy: A cross-sectional study. Eur Spine J 2014;23:916-921.

4. Dillingham T. Electrodiagnostic approach to patients with suspected radiculopathy. Phys Med Rehabil Clin N Am 2002;13:567-588.

5. Ashkan K, Johnston P, Moore AJ. A comparison of magnetic resonance imaging and neurophysiological studies in the assessment of cervical radiculopathy. British Journal of Neurosurgery 2002;16:146-148.

6. So YT, Weber CF, Campbell WW. American association of electrodiagnostic medicine, American academy of physical medicine and rehabilitation practice parameter for needle electromyographic evaluation of patients with suspected cervical radiculopathy: Summary statement. Muscle Nerve 1999;22:209211.

7. Nardin R, Patel M, Gudas T, Rutkove S, Raynor E. Electromyography and magnetic resonance imaging in the evaluation of radiculopathy. Muscle Nerve 1999;22:151-S155.

8. Lee JH, Lee SH. Physical examination, magnetic resonance imaging, and electrodiagnostic study of patients with lumbosacral disc herniation or spinal stenosis. J Rehabil Med 2012;44:845-850.

9. Robinson LR. Electromyography, magnetic resonance imaging, and radiculopathy: It's time to focus on specificity. Muscle Nerve 1999;22:149150.

10. Coster S, de Brujin S, Tavy J. Diagnostic value of history, physical examination and needle electromyography in diagnosing lumbosacral radiculopathy. J Neurol 2010;257:332-337.

11. Levin $\mathrm{KH}$. Electromyography and magnetic resonance imaging in the evaluation of radiculopathy. Muscle Nerve 1999;8:1158-1159.

12. Inal EE, Eser F, Aktekin LA, Öksüz E, Bodur H. Comparison of clinical and electrophysiological findings in patients with suspected radiculopathies. Journal of Back and Musculoskeletal Rehabilitation 2013;26:169-173.

13. Tsao B. The electrodiagnosis of cervical and lumbosacral radiculopathy Neurol Clin 2007;25:473-494.

14. Dillingham TR, Pezzin LE, Lauder TD, Andary M, Kumar S, Stephens RT. Steven S. Symptom duration and spontaneous activity in lumbosacral radiculopathy. Am J Phys Med Rehabil 2000;79:124-132.

15. Pezzin LE, Dillingham TR, Lauder TD, Andary M, Kumar S, Stephens RR, Shannon S. Cervical radiculopathies: Relationship between symptom duration and spontaneous EMG activity. Muscle Nerve 1999;22:1412-1418. 